\title{
Hydrolysis of the Elastase Substrate Succinyltrialanine Nitroanilide by a Metal-Dependent Enzyme in
} Rheumatoid Synovial Fluid

\author{
JEREMY SAKLATVALA \\ From The Center for Rheumatic Diseases and University Department of Medicine, Royal Infirmary, \\ Glasgow, Scotland
}

\begin{abstract}
A B S T RACT A new type of enzyme hydrolyzing the elastase substrate succinyl-L-alanyl-L-alanyl-L-alanine-4-nitroanilide has been found in cell-free rheumatoid synovial fluid. Normal plasma and osteoarthritic synovial fluid contained relatively little enzyme. The $\mathrm{pH}$ optimum was 8.0. Unexpectedly, the enzyme activity was not due to leukocyte elastase or any proteinase bound to $\alpha_{2}$-macroglobulin. The enzyme activity was metal-dependent being inhibited by chelating agents but not by di-isopropylfluorophosphate or thiol-blocking reagents. Gel chromatography showed the enzyme activity was associated with material of high molecular weight. On Sepharose 4B chromatography two-thirds of the activity eluted in the void volume and one-third in a position of about $10^{6} \mathrm{~mol}$ wt. Ultracentrifugation showed that both components were associated with lipid. The buoyant density of the higher molecular weight material was $1.15-1.22 \mathrm{~g} / \mathrm{ml}$., and that of lower molecular weight material was $1.2-1.33 \mathrm{~g} / \mathrm{ml}$. No latency of the enzyme was revealed by freezing and thawing or treatment with detergents. The nature of the enzyme is discussed. It is likely to be a proteinase possibly bound to some kind of membrane fragment.
\end{abstract}

\section{INTRODUCTION}

It has been frequently postulated that tissue destruction in rheumatoid arthritis may be caused by lysosomal proteinases $(1,2)$. Of particular interest are the proteinases of the neutrophilic polymorphonuclear leukocytes, since large numbers of these cells are found in rheumatoid synovial fluid. Detailed studies

\footnotetext{
Dr. Saklatvala's present address is Strangeways Research Laboratory, Worts' Causeway, Cambridge, England.

Received for publication 21 May 1976 and in revised form 9 January 1977.
}

of the action of these proteinases on cartilage proteoglycan have been reported recently $(3,4)$. Three proteinases from human neutrophils have been described, and all are optimally active near physiological $\mathrm{pH}$ : leukocyte elastase $(5,6)$ a chymotrypsin-like enzyme now called cathepsin $G(7,8)$ and a collagenase $(9,10)$. Synovial fluid contains potent inhibitors of these enzymes, the major ones being $\alpha_{1}$-proteinase inhibitor and $\alpha_{2}$-macroglobulin $\left(\alpha_{2} M\right){ }^{1}{ }^{1}$ Ohlsson (11) has shown by immunological techniques that rheumatoid synovial fluid contains complexes of neutrophil proteinases with the inhibitors, which suggests that the proteinases are being released from the cells into the fluid.

Complexes of proteinase and $\alpha_{1}$-proteinase inhibitor are catalytically inactive, but complexes of proteinase with $\alpha_{2} \mathrm{M}$ will hydrolyze low molecular weight substrates $(12,13)$. The work to be described arose from an attempt to detect leukocyte elastase bound to $\alpha_{2} \mathrm{M}$ in rheumatoid synovial fluid by using the highly specific and stable elastase substrate succinyl-L-alanylL-alanyl-L-alanine-4-nitroanilide (Suc- $\mathrm{Ala}_{3}-\mathrm{NPhNO}_{2}$ ) (14). Rheumatoid synovial fluid was found to contain enzymic activity that hydrolyzed this substrate but it was not attributable to leukocyte elastase because inhibition experiments showed that the activity was metal-dependent and did not have the characteristics of a serine enzyme. Nor was the activity associated with $\alpha_{2} M$, so it was not due to a complex of proteinase with this protein.

Finding a metal-dependent enzyme hydrolyzing the elastase substrate was of great interest because it was likely to be a proteinase, and was a hitherto unrecog-

\footnotetext{
${ }^{1}$ Abbreviations used in this paper: $\alpha_{2} \mathrm{M}, \alpha_{2}$-macroglobulin; Suc- $\mathrm{Ala}_{3}-\mathrm{NPhNO}_{2}$, succinyl-L-alanyl-L-alanine-4-nitroanilide; Dip-F, di-isopropylfluorophosphate; Pms-F, phenylmethanesulfonylfluoride; $\rho$, density.
} 
nized enzyme in rheumatoid synovial fluid which could be involved in tissue destruction. Further experiments were done to attempt to isolate and characterize the enzyme responsible for the activity.

\section{METHODS}

\section{Materials}

All chemicals used were analytical reagent grade and obtained from British Drug Houses, Ltd., Poole, Dorset, England, except where specified.

Synovial fluid and plasma. Synovial fluid was aspirated from knee joints of 21 patients with rheumatoid arthritis and put into sterile plastic containers. According to the American Rheumatism Association critera, 18 had classical rheumatoid arthritis and 3 had definite rheumatoid arthritis. The latter all had a negative sheep cell agglutination test for rheumatoid factor while the former were all positive. The ages of the patients ranged from 30 to $70 \mathrm{yr}$. Blood samples were taken simultaneously with the synovial fluid from 11 patients and put into heparinized tubes, from these the plasma was separated. After leukocyte counts, the leukocytes were separated from the synovial fluid by centrifugation at $3,000 \mathrm{rpm}$ for $20 \mathrm{~min}$ at $4^{\circ} \mathrm{C}$. Fluid was stored at $4^{\circ} \mathrm{C}$ and assayed for enzymic activity within $24 \mathrm{~h}$. Samples of synovial fluid for chromatography and ultracentrifugation were treated with ovine hyaluronidase (hyalase, Fisons Ltd., Loughborough, England). 10 manufacturer's U were added per $1 \mathrm{ml}$ of synovial fluid and the fluid was incubated at $37^{\circ} \mathrm{C}$ for $20 \mathrm{~min}$. The hyaluronidase preparation caused no hydrolysis of Suc-(Ala $)_{3}-\mathrm{NPhNO}_{2}$ at the concentration used.

Synovial fluid was also taken from knee joints of five patients with osteoarthritis. These were noninflammatory effusions, all with leukocyte counts $<1,000$ per $\mathrm{mm}^{3}$, and were treated in the same way as rheumatoid fluid. Plasma (heparinized) was obtained from 15 normal volunteers of ages 25$60 \mathrm{yr}$.

Synovial fluid cell extracts. The leukocyte pellet from 25 $\mathrm{ml}$ of synovial fluid was washed three times with $0.9 \%$ $\mathrm{NaCl}$, suspended in $4 \mathrm{ml}$ of $0.1 \mathrm{M}$ Tris- $\mathrm{HCl}$ buffer, $\mathrm{pH} \mathrm{8.0,}$ and subjected to ultrasonic disintegration for $1 \mathrm{~min}$ at amplitude $8 \mu \mathrm{m}$ peak to peak in a Measuring and Scientific Equipment $100 \mathrm{~W}$ Ultrasonic Disintegrator (Measuring and Scientific Equipment Ltd., Crawley, Sussex, England). The sonicate was centrifuged at $3,000 \mathrm{rpm}$ for $10 \mathrm{~min}$ to remove unbroken cells and coarse debris, and the supernate was kept at $4^{\circ} \mathrm{C}$ till use.

Gel chromatography. Columns of Sephadex G-150 and Sepharose 4B (Pharmacia Ltd., London, W5 5SS, England) were run at room temperature with $0.1 \mathrm{M}$ Tris- $\mathrm{HCl}$ buffer $\mathrm{pH} 8,0$. Eluates were concentrated by ultrafiltration in a Diaflo apparatus (Amicon Ltd., High Wycombe, Buckinghamshire, England).

Electrophoresis. Electrophoresis was in polyacrylamide gel cylinders $0.3 \times 6 \mathrm{~cm}(1.2 \mathrm{ml})$ containing $5 \%$ acrylamide monomer and $0.25 \% \mathrm{~N}, \mathrm{~N}^{\prime}$-methylene bis-acrylamide in 0.35 $\mathrm{M}$ Tris- $\mathrm{HCl}$ buffer $\mathrm{pH}$ 8.9. Samples (up to $50 \mu \mathrm{l}$ ) were applied to the top of a $2.5 \%$ acrylamide stacking gel $(0.1 \mathrm{ml})$ containing $0.06 \mathrm{M}$ Tris-phosphate buffer, $\mathrm{pH} 7.2$. Gels were polymerized with ammonium persulphate, and electrophoresis was carried out towards the anode for $2 \mathrm{~h}$ at $2 \mathrm{~mA} / \mathrm{gel}$ at $4^{\circ} \mathrm{C}$ with $52 \mathrm{mM}$ Tris-glycine buffer $\mathrm{pH} 8.9$ in the cathode reservoir and $0.1 \mathrm{M}$ Tris- $\mathrm{HCl} \mathrm{pH} 8.1$ in the anode reservoir. Gels were stained with amido black or sectioned transversely into 4-mm slices. Protein was eluted from the slices by homogenizing them in $0.1 \mathrm{M}$ Tris- $\mathrm{HCl}$ buffer, $\mathrm{pH} 8.0$, and leaving them overnight at $4^{\circ} \mathrm{C}$. Gel fragments were removed by centrifugation. For electrophoresis of mixtures of $\alpha_{2} \mathrm{M}$ and extracts of rheumatoid synovial fluid cells, the mixture was made in the presence of $1 \mathrm{M} \mathrm{KCl}$ and $0.1 \%$ Triton X-100 to solubilize leukocyte elastase (15).

Ultracentrifugation. Samples of synovial fluid $(3 \mathrm{ml})$ were adjusted to the required density by addition of solid potassium bromide or sucrose, and were overlayered with $7 \mathrm{ml}$ of $0.1 \mathrm{M}$ Tris- $\mathrm{HCl}$ buffer, $\mathrm{pH} \mathrm{8.0,} \mathrm{which} \mathrm{had} \mathrm{been}$ adjusted to the same density with potassium bromide or sucrose. Centrifugation was performed in a Measuring and Scientific equipment Superspeed 75 centrifuge (Measuring and Scientific Equipment Ltd.) by using the Ti ioxio $10 \times 10$ $\mathrm{ml}$ rotor at $50,000 \mathrm{rpm}$ for $20 \mathrm{~h}$ at $15^{\circ} \mathrm{C}$. The tube contents were collected in 2-ml fractions which were dialyzed against two changes of the Tris buffer at $4^{\circ} \mathrm{C}$ and then assayed for enzymic activity.

Purification of $a_{2}-M . \quad \alpha_{2} \mathrm{M}$ was purified from fresh human plasma as follows: after gel filtration of $15 \mathrm{ml}$ of plasma on a $5 \times 100-\mathrm{cm}$ column of Sephadex G-150, the void volume peak was concentrated to $10 \mathrm{ml}$, adjusted to $35 \%$ saturation with ammonium sulphate, and the precipitate was removed by centrifugation. The supernate was dialyzed against 10 $\mathrm{mM}$ Tris- $\mathrm{HCl}$ buffer $\mathrm{pH} 8.0$ and subjected to preparative electrophoresis with a Buchler Polyprep apparatus (Nuclear Chicago Corp., Des Plaines, Ill.) according to the makers' instructions. The resolving gel $(3 \mathrm{~cm}$ length) contained $4 \%$ acrylamide and $0.25 \%$ agarose; the buffer system was as described for analytical electrophoresis. Eluate fractions containing $\alpha_{2} \mathrm{M}$ were pooled and concentrated by ultrafiltration. Details of this procedure have been described elsewhere (16).

Enzyme assays. Hydrolysis of Suc- $-\mathrm{Ala}_{3}-\mathrm{NPhNO}_{2}($ Bachem Fine Chemicals, Inc., Marina del Rey, Calif.) by synovial fluid was measured spectrophotometrically. The assay buffer was $0.1 \mathrm{M}$ Tris- $\mathrm{HCl}, \mathrm{pH} 8.0$. Up to $0.75 \mathrm{ml}$ of plasma or synovial fluid was added to $0.75 \mathrm{ml}$ of $2 \mathrm{mM}$ Suc(Ala) ${ }_{3}-\mathrm{NA}$ and the mixture was incubated for $4 \mathrm{~h}$ at $37^{\circ} \mathrm{C}$ (assay vol $1.5 \mathrm{ml}$ ). $0.5 \mathrm{ml}$ of $12 \%$ trichloroacetic acid was added and the precipitate was removed by centrifugation at 10,000 $\mathrm{rpm}$ for $15 \mathrm{~min}$. To $1 \mathrm{ml}$ of the supernate, $0.1 \mathrm{ml}$ of $1.84 \mathrm{M}$ $\mathrm{NaOH}$ was added to restore the $\mathrm{pH}$ to about 7 . The absorbance at $410 \mathrm{~nm}$ of the solutions was then read against control assays to which substrate was added at the end of the incubation. Precipitation of protein by trichloroacetic acid was necessary to remove the high background absorbance of the assays and controls. Restoration of the $\mathrm{pH}$ to neutral by addition of $\mathrm{NaOH}$ was necessary because the nitroaniline color disappears below $\mathrm{pH} 2.5$, but can be restored by raising the $\mathrm{pH}$, and is constant between $\mathrm{pH} 3$ and 10 . Above $\mathrm{pH}$ 10, nitroaniline absorbance increases sharply and at strongly alkaline $\mathrm{pH}$ hydrolysis of Suc-(Ala) ${ }_{3}$-NA occurs (17). Acid precipitation of the protein did not cause significant hydrolysis of the substrate or destruction of nitroaniline. In the assay, the absorbance change at $410 \mathrm{~nm}$ was linearly related to the amount of fluid added. Enzyme activity was expressed as nanomoles of substrate hydrolyzed per hour per milliliter of synovial fluid or plasma under the conditions of the assay. Identical results were found with plasma and serum. The spontaneous hydrolysis of the substrate over the incubation period used was very little $(0.07 \%$ $\mathrm{h}, \mathrm{pH} 8.0[14])$. The very low blank values $\left(\mathrm{A}_{410}=0.01-0.03\right)$ enabled precise measurements of low rates of substrate hydrolysis.

Fractions from chromatography, ultracentrifugation, and electrophoresis were assayed for enzymic activity by adding 


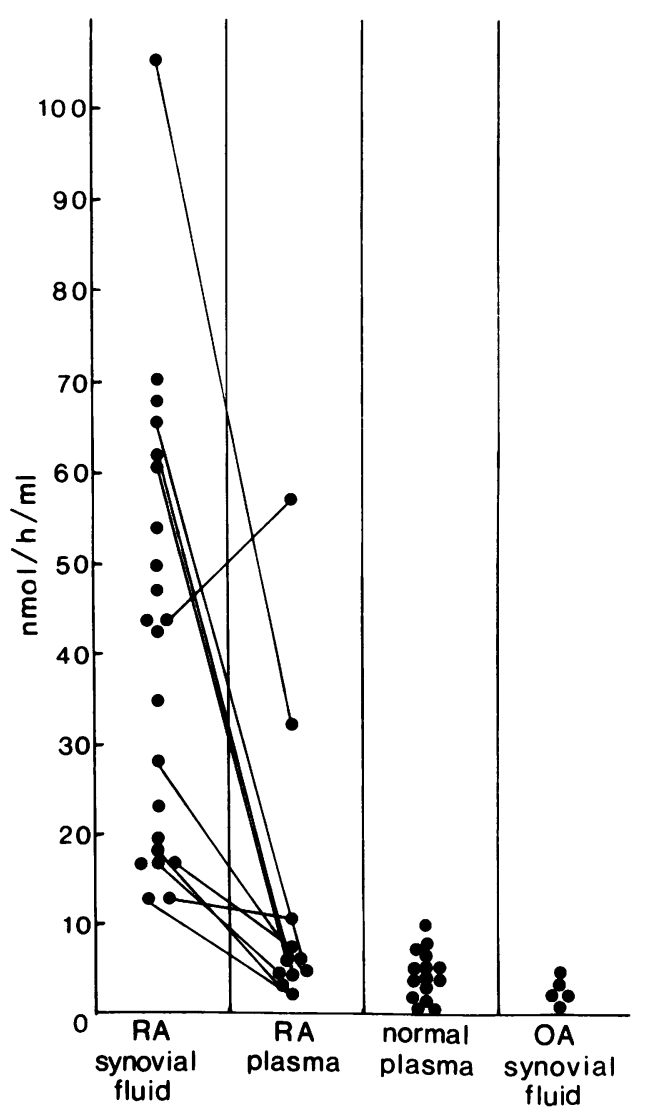

FIGURE 1 Hydrolysis of Suc-(Ala $)_{3}-\mathrm{NPhNO}_{2}$ by synovial fluid and plasma.

$0.1 \mathrm{ml}$ of $10 \mathrm{mM}$ Suc-Ala $-\mathrm{NPhNO}_{2}$ to $1 \mathrm{ml}$ of the fraction. After incubation for the specified time $(1-8 \mathrm{~h})$ the absorbance change at $410 \mathrm{~nm}$ was measured against a control assay to which substrate was added after incubation. For inhibition of nitroanilide hydrolase activity, inhibitors were preincubated with enzyme solution for $20 \mathrm{~min}$ at room temperature before addition of substrate. In some experiments di-isopropylfluorophosphate (Dip-F) was preincubated with enzyme for up to $10 \mathrm{~h}$. Dip-F, phenylmethane sulfonylfluoride (Pms-F), 1, 10 phenanthroline, EDTA, p-chloromercuribenzoic acid, iodoacetamide, soybean trypsin inhibitor, and Triton X-100 were all from Sigma Chemical Co., Ltd., London, England. Basic pancreatic trypsin inhibitor was Trasylol from Bayer AG, Wuppertal-Elberfeld, Germany.

Inhibition of chymotrypsin activity (Bovine chymotrypsin Type II, Sigma Chemical Co., Ltd.) and proteolytic activity of rheumatoid synovial fluid leukocyte extracts by $\alpha_{2} M$ was measured by use of the substrate hide-power azure (Calbiochem Ltd., Hereford, HR4 9BO, England) as described elsewhere (18).

Ultracentrifuge fractions of synovial fluid were assayed for proteolytic activity by use of azocasein substrate (Sigma Chemical Co., Ltd.) (19), hide-power azure and Remazol brilliant blue dyed elastin (15). These assays were done with $0.1 \mathrm{M}$ Tris- $\mathrm{HCl}$ buffer, $\mathrm{pH} 8.0$, containing $0.1 \%$ Triton $\mathrm{X}-100$. Reaction mixtures were incubated for periods up to $10 \mathrm{~h}$ at $37^{\circ} \mathrm{C}$.

\section{RESULTS}

Detection of hydrolysis of succinyltrialanine nitroanilide. Rheumatoid synovial fluid contained more enzymic activity hydrolyzing Suc- $\mathrm{Ala}_{3}-\mathrm{NPhNO}_{2}$ than normal plasma or osteoarthritic synovial fluid (Fig. 1). Two samples of rheumatoid plasma also contained a high level of enzymic activity. Apart from one patient, the synovial fluid levels were higher than the plasma levels. The enzymic activity in synovial fluid correlated poorly with the total leukocyte counts and the linear regression coefficient, $r=0.464$ was only significant at the $5 \%$ level (Student's $t$ test $=2.29$, degrees of freedom $=15$ ).

The enzymic activity was independent of ionic strength (I) in the range $\mathrm{I}=0.1-1.0$ and the $\mathrm{pH}$ dependence is shown in Fig. 2. There is a sharp optimum at $\mathrm{pH} 8.0$ and no detectable actvity below $\mathrm{pH} 6.0$. The assay could not be used above $\mathrm{pH} 10.0$ because of the susceptibility of nitroanilides to hydrolysis at alkaline $\mathrm{pH}$.

To investigate possible latency of the enzymic activity in rheumatoid synovial fluid, five samples were assayed after rapidly freezing and thawing six times, and in the presence of $0.1 \%$ Triton $\mathrm{X}-100$. In three fluids $0.1 \%$ Triton $\mathrm{X}-100$ caused slight increases of activity (up to 20\%) in the other two there was no effect. Freezing and thawing caused no change in the activity.

Sephadex gel chromatography. Fractionation on Sephadex G-150 of rheumatoid synovial fluid (Fig. 3a) and rheumatoid plasma (Fig. $3 b$ ) containing high levels of nitroanilide hydrolase activity showed that all of the enzyme activity was associated with high molecular weight material eluting in the void volume. The recovery of activity in these experiments was $90-95 \%$.

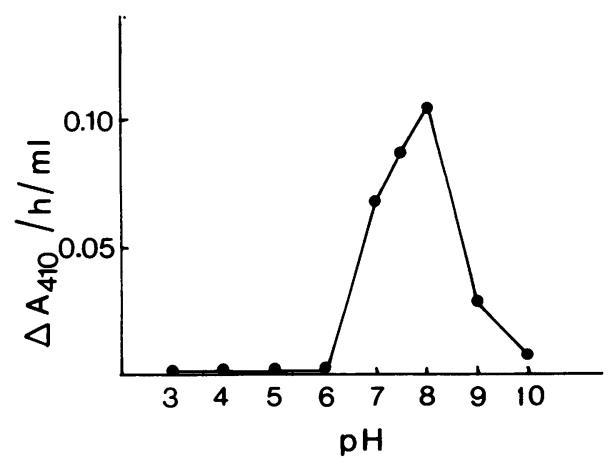

Figure 2 Effect of $\mathrm{pH}$ on hydrolysis of Suc-(Ala) $)_{3}-\mathrm{NPhNO}_{2}$ by rheumatoid synovial fluid. Assay buffers used were $\mathrm{pH}$ 3-6; 0.1 M citrate, pH 7-9: 0.1 M Tris-HCl, pH 10: $0.1 \mathrm{M}$ glycine- $\mathrm{NaOH}$. Enzyme activity is expressed as absorbance change $\left(\Delta \mathbf{A}_{410}\right)$ /hour per milliliter synovial fluid added to the assay. 


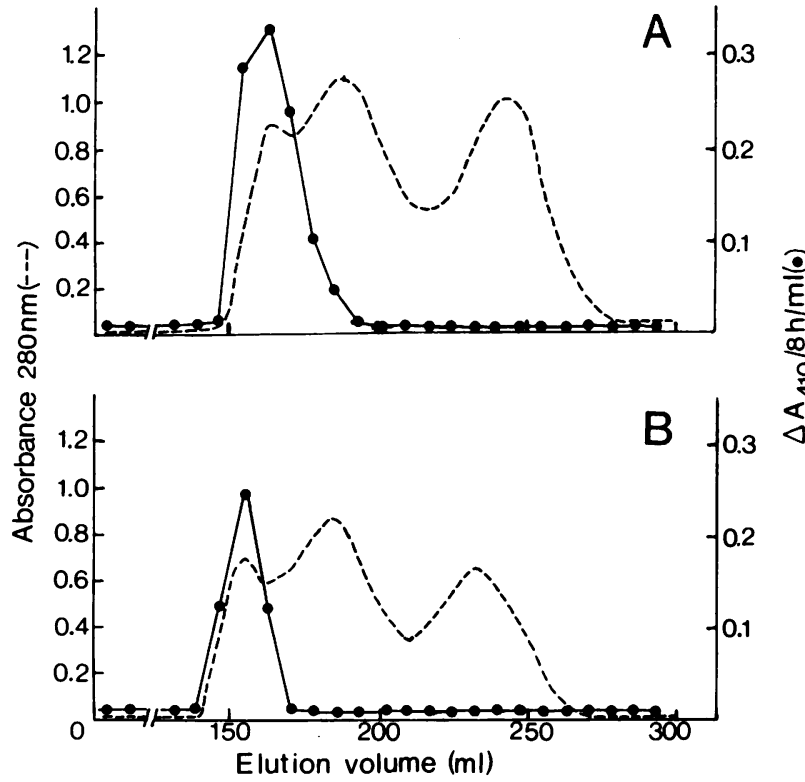

FIGURE 3 Sephadex G150 chromatography of rheumatoid synovial fluid (A) and rheumatoid plasma (B). Column 2.5 $\times 75 \mathrm{~cm}$; samples: $2 \mathrm{ml}$ synovial fluid, $1 \mathrm{ml}$ plasma. Absorbance at $280 \mathrm{~nm}(---)$, hydrolysis of Suc(Ala) ${ }_{3}-\mathrm{NPhNO}_{2}$ expressed as absorbance change $\left(\Delta \mathrm{A}_{410}\right) / 8 \mathrm{~h}$ per $\mathrm{ml}$ of fraction (๑).

This result was compatible with the idea that the substrate was being hydrolyzed by leukocyte elastase bound to $\alpha_{2} \mathrm{M}$. Leukocyte elastase is a serine proteinase and is inhibited by compounds such as Dip-F and Pms-F which react with the serine residue in its active site $(5,6)$ so the effect of various proteinase inhibitors on the synovial fluid nitroanilide hydrolase activity was studied.

Inhibition of the hydrolysis of succinyltrialanine nitroanilide. The results of inhibition studies are shown in Table 1. The enzymic activity was not attributable to a serine proteinase since it was not inhibited by Dip-F (preincubated up to $10 \mathrm{~h}$ ) or Pms-F. The activity was not significantly inhibited by the thiol blocking agents p-chloromercuribenzoate and iodoacetamide, but it was inhibited by the chelating agents EDTA and 1,10 phenanthroline, showing that the enzymic activity was metal dependent. The failure of soybean trypsin inhibitor or Trasylol to inhibit the activity was not surprising since these are serine proteinase inhibitors, although it is conceivable that if the enzyme were present in complexes with another macromolecule it might be sterically hindered from reacting with the higher molecular weight inhibitors.

Polyacrylamide gel electrophoresis. The possibility that the enzymic activity might be due to elastase or some other proteinase bound to $\alpha_{2} \mathrm{M}$ was ex- plored further by using electrophoresis. The following preliminary experiments showed that polyacrylamide gel electrophoresis was a suitable method for detecting $\alpha_{2} \mathrm{M} /$ proteinase complexes. The change in the electrophoretic behaviour of $\alpha_{2} \mathrm{M}$ caused by adding a proteinase to it is shown in Fig. 4. Saturation of $\alpha_{2} \mathrm{M}$ with chymotrypsin caused the $\alpha_{2} \mathrm{M}$ to run slightly ahead of the native $\alpha_{2} M$ position (gels $a$ and $b$ ). Addition of enough chymotrypsin to react with half of the $\alpha_{2} \mathrm{M}$ (determined from proteolytic inhibition assays) resulted in about half of the protein running in the faster band (complex) and half in the slower band (free $\alpha_{2} \mathrm{M}$ ) (gel c). Chymotrypsin itself is a cationic protein and does not run into the gel.

A further experiment in which an extract of rheumatoid synovial fluid cells (which are rich in leukocyte elastase 15,20 ) was added to $\alpha_{2} \mathrm{M}$ showed a similar result (gels $\mathrm{d}$ and e). Gels containing $\alpha_{2} \mathrm{M}$ saturated with the cell extract (gel d) were sliced and protein was eluted from the homogenized slices.

The eluates $(1 \mathrm{ml})$ were assayed for elastase activity by hydrolysis of Suc- $\mathrm{Ala}_{3}-\mathrm{NPhNO}_{2}$. The upper part of Fig. 5 shows that the enzyme was found in the slice corresponding to the $\alpha_{2} M$ position. The activity was abolished by preincubation of the eluates with Dip-F. Control gels in which rheumatoid synovial fluid cell extract was run alone yielded no enzyme activity (not shown). Leukocyte elastase itself is a cationic protein and does not enter the gel under these conditions.

It had thus been shown that $\alpha_{2} \mathrm{M} /$ proteinase com-

TABLE I

Effect of Inhibitors on Hydrolysis of Suc-(Ala $)_{3} \mathrm{NPhNO}_{2}$ by Rheumatoid Synovial Fluid

\begin{tabular}{lcc}
\hline \multicolumn{1}{c}{ Compound } & Concentration & $\begin{array}{c}\text { Change of } \\
\text { activity }\end{array}$ \\
\hline & & $\%$ \\
$\begin{array}{l}\text { Diisopropylfluorophosphate } \\
\begin{array}{l}\text { Phenylmethanesulfonyl } \\
\quad \text { fluoride }\end{array}\end{array}$ & $1 \mathrm{mM}$ & 0 \\
p-Chloromercuribenzoic acid & $1 \mathrm{mM}$ & 0 \\
$\begin{array}{l}\text { Iodoacetamide } \\
\text { Cysteine }\end{array}$ & $2 \mathrm{mM}$ & 0 \\
$\begin{array}{l}\text { Ethylenediamine tetra-acetic } \\
\text { acid }\end{array}$ & $5 \mathrm{mM}$ & -15 \\
$\begin{array}{l}\text { Ethylenediamine tetra-acetic } \\
\quad \text { acid }\end{array}$ & $2 \mathrm{mM}$ & -90 \\
$\begin{array}{l}\text { 1, 10-Phenanthroline } \\
\text { Soybean trypsin inhibitor }\end{array}$ & $5 \mathrm{mM}$ & -95 \\
Basic pancreatic trypsin & $100 \mu \mathrm{mM}$ & -95 \\
$\quad$ inhibitor (Trasylol) & $100 \mathrm{U} / \mathrm{ml}$ & 0 \\
\hline
\end{tabular}

Inhibition is expressed as percentage change of activity of control assays done without inhibitor. 


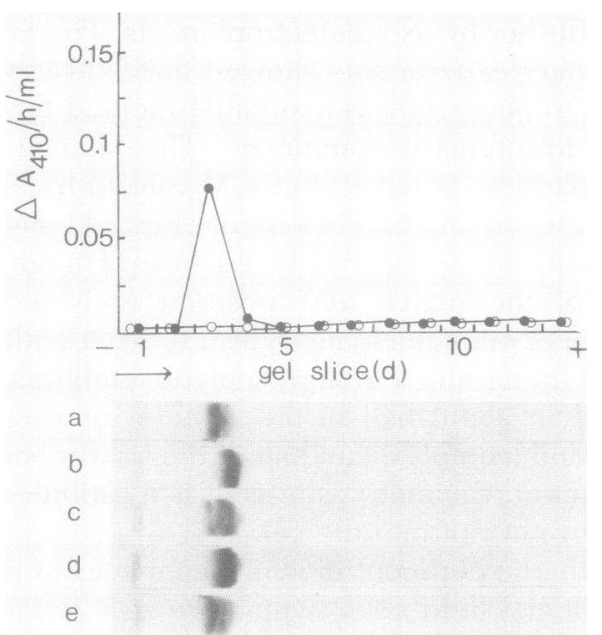

FIGURE 4 Polyacrylamide gel electrophoresis of mixtures of $\alpha_{2}-\mathrm{M}$ and proteinases. (a) $30 \mu \mathrm{g} \alpha_{2} \mathrm{M}$, (b) $\alpha_{2} \mathrm{M}$ saturated with chymotrypsin. Equireactant amounts were calculated from proteolytic inhibition. (c) $\alpha_{2} M$ half saturated with chymotrypsin, (d) $\alpha_{2} M$ saturated with rheumatoid synovial fluid cell extract, (e) $\alpha_{2} \mathrm{M}$ half saturated with rheumatoid synovial fluid cell extract. The arrow marks the direction of migration. The line diagram shows the hydrolysis of Suc(Ala) $3^{-}$ $\mathrm{NPhNO}_{2}$ by eluates from sliced gels run with equireactant amounts of $\alpha_{2} \mathrm{M}$ and rheumatoid synovial fluid leukocyte extract (same as gel d). $O$, eluates treated with DFP (1 mM) for $20 \mathrm{~min}$ before addition of substrate; $\bigcirc$, not treated with DFP. See under Methods for details of electrophoretic conditions.

plexes run slightly ahead of free $\alpha_{2} \mathrm{M}$ in this electrophoretic system, and that it was possible to elute the complexes from the gel to detect their enzymic activity, and that this activity was inhibited by Dip-F in the case of a serine proteinase. The purified $\alpha_{2} M$ (gel a) contained a small amount of protein running ahead of the main band and this could represent a trace of $\alpha_{2} \mathrm{M} /$ proteinase complex, denatured $\alpha_{2} \mathrm{M}$, or impurity.

To see if the nitroanilide hydrolase activity in synovial fluid was associated with $\alpha_{2} M$, active fractions from Sephadex G-150 chromatography were concentrated by ultrafiltration and run in electrophoresis. Gels were stained for protein or sliced and protein eluted; the eluates were assayed for hydrolysis of Suc-Ala $-\mathrm{NPhNO}_{2}$ (Fig. 5a). 95\% of the activity failed to enter the resolving gel, being trapped in the first slice, but there was a small peak of activity (representing about 5\% of the activity) in the region of $\alpha_{2} \mathrm{M}$. Fig. 5b shows a similar experiment with activity from rheumatoid plasma after Sephadex G-150 chromatography; all the activity recovered was in the first gel slice. The overall recovery of activity from electrophoresis was about $40 \%$. The recovery of $50-60 \%$ of $\alpha_{2} M$ (measured as chymotrypsin inhibition) in these experiments showed that protein elution was satis- factory. An identical distribution of enzymic activity was found when whole synovial fluid or plasma was run on electrophoresis. The enzymic activity that was eluted from the first gel slice was not inhibited by Dip-F.

These results gave no support to the idea that the hydrolysis of Suc-Ala ${ }_{3}-\mathrm{NPhNO}_{2}$ was due to leukocyte elastase or any other proteinase bound to $\alpha_{2} \mathrm{M}$. Rather they suggested that the enzyme was of very high molecular weight or was associated with some high molecular weight protein other than $\alpha_{2} \mathrm{M}$.

Ultracentrifugation. These experiments were done to see if the enzyme activity was associated with lipid-containing material rather than with $\alpha_{2} \mathrm{M}$. The synovial fluid was centrifuged at starting densities $1.006,1.063$, and $1.225 \mathrm{~g} / \mathrm{ml}$. These were chosen because they are standard densities used for flotation of very low density, low density and high density lipoproteins, respectively (21). Either sucrose or $\mathrm{KBr}$ was used to adjust the density with essentially the

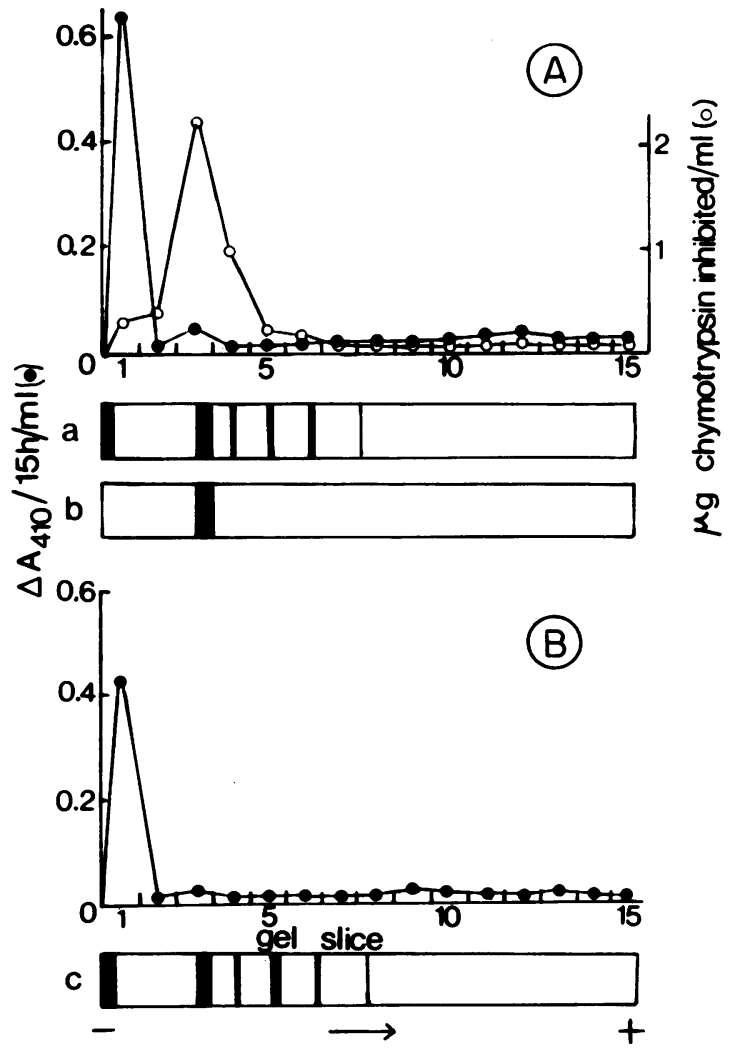

FIGURE 5 Polyacrylamide gel electrophoresis of the nitroanilide hydrolase activity from rheumatoid synovial fluid (A) and plasma (B). Samples were from Sephadex G150 chromatography void volume peak. Gel (a) (synovial fluid) and gel (c) (plasma), show distribution of protein, gel (b) is pure $\alpha_{2} M$. Eluates of gel slices were assayed for hydrolysis of Suc(Ala) $)_{3}-\mathrm{NPhNO}_{2}(\Theta)$, and inhibition of chymotrypsin ( $O$, shown in A only). 
same results. After $20 \mathrm{~h}$ centrifugation at $50,000 \mathrm{rpm}$ the enzymic activity sedimented to the bottom of the tube at $\rho=1.006$ and $1.063 \mathrm{~g} / \mathrm{ml}$, but $75 \%$ of it floated in the top fraction at $\rho=1.225 \mathrm{~g} / \mathrm{ml}$ (Fig. 6). Five samples of synovial fluid gave similar results and the overall recovery was $\mathbf{7 0 - 8 0 \%}$. Evidently a major part of the enzymic activity was associated with lipid.

The material buoyant at $1.225 \mathrm{~g} / \mathrm{ml}$ was also assayed for proteinase activity. The sample from one synovial fluid hydrolyzed azocasein in the presence of $0.1 \%$ Triton X-100. No activity was observed without detergent and the activity was inhibited by Dip-F and not EDTA. The samples from the other four synovial fluids did not hydrolyze azocasein. None of the samples hydrolyzed hide-powder azure or Remazol brilliant blue-elastin. It was concluded that there was no detectable proteinase activity attributable to the enzyme hydrolysing Suc-(Ala) $)_{3}-\mathrm{NPhNO}_{2}$. The proteinase activity found in the one sample was due to a serine proteinase.

Sepharose $4 B$ gel chromatography. The concentrate from the Sephadex G-150 column (Fig. 3a) was fractionated further on Sepharose 4B (Fig. 7). 65\% of the enzymic activity recovered was in the void volume and the remainder in the first part of the main protein peak. The main peak corresponds to $\alpha_{2} M$ as shown by chymotrypsin inhibition: note that the second enzyme peak does not correspond to the $\alpha_{2} M$

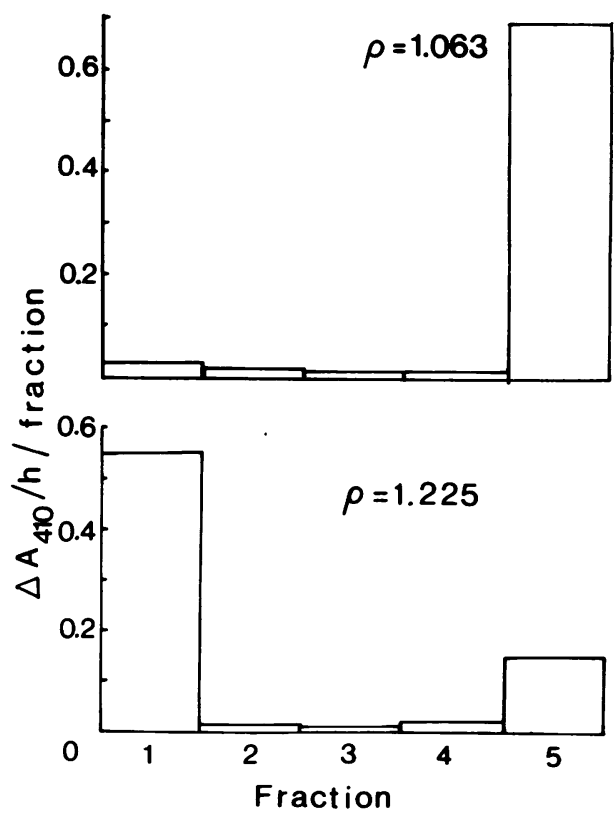

FIGURE 6 Ultracentrifugation of rheumatoid synovial fluid. The histograms show the distribution of enzyme hydrolysing Suc-(Ala) $)_{3}-\mathrm{NPhNO}_{2}$. Fraction $1=$ top of tube, fraction 5 $=$ bottom of tube. $3 \mathrm{ml}$ of rheumatoid synovial fluid were centrifuged in total volume of $10 \mathrm{ml}$. Density adjusted with $\mathrm{KBr}$. Centrifugation at $50,000 \mathrm{rpm}, 20 \mathrm{~h}, 15^{\circ} \mathrm{C}$.

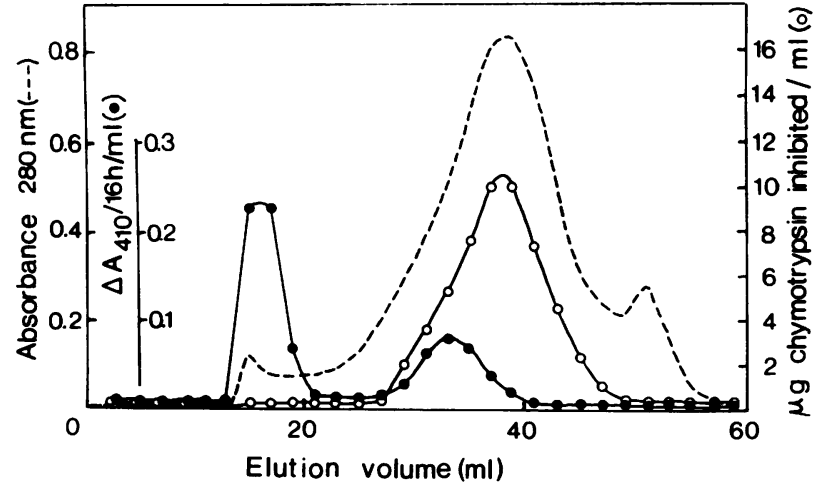

FIGURE 7 Sepharose 4B chromatography of void volume peak from Sephadex G150 chromatography or rheumatoid synovial fluid. Column $15 \times 30 \mathrm{~cm}$. Absorbance at $280 \mathrm{~nm}$ $(---)$, hydrolysis of Suc-(Ala $)_{3}-\mathrm{NPhNO}_{2}(\mathbf{O})$, inhibition of chymotrypsin $(O)$.

peak. A similar distribution was obtained on chromatography of whole synovial fluid and in both experiments the overall recovery of activity was about $80 \%$. On rechromatography the active peaks eluted in their original positions. Inhibition studies on the enzymic activity in the two peaks showed that it was inhibited by EDTA and not Dip-F.

Because ultracentrifugation had shown that a major part of the enzymic activity was of buoyant density $<1.225 \mathrm{~g} / \mathrm{ml}$, experiments were done to determine the buoyant densities of the enzymic activity in the two Sepharose 4B peaks. The active peaks were concentrated by ultrafiltration and $1-\mathrm{ml}$ samples were ultracentrifuged at starting densities in the range 1.1-1.33 $\mathrm{g} / \mathrm{ml}$ at $50,000 \mathrm{rpm}$ for $20 \mathrm{~h}$ at $15^{\circ} \mathrm{C}$. Densities were adjusted by addition of solid $\mathrm{KBr}$ and the enzyme solutions were overlayered with $9 \mathrm{ml}$ of $\mathrm{KBr}$ solution. After centrifugation the tube contents were collected as $3.3-\mathrm{ml}$ fractions, dialyzed against $0.1 \mathrm{M}$ Tris-

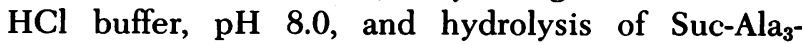
$\mathrm{NPhNO}_{2}$ was measured. The percentage of total activity recovered in the top fraction (i.e. buoyant) was plotted against the starting density (Fig. 8). The enzymic activities in the two Sepharose 4B peaks were clearly of different buoyant densities. The activity in the void volume peak became buoyant over the starting density range $1.15-1.22 \mathrm{~g} / \mathrm{ml}$, and the activity in the second peak over the range 1.2-1.33 $\mathrm{g} / \mathrm{ml}$. Since protein has a density of about $1.37 \mathrm{~g} / \mathrm{ml}$ it can be concluded from the low buoyant density of the enzymic activity in both Sepharose $4 \mathrm{~B}$ peaks that the enzyme was associated with lipid as well as protein.

\section{DISCUSSION}

The results of the inhibition experiments, electrophoresis, and ultracentrifugation showed that the major 


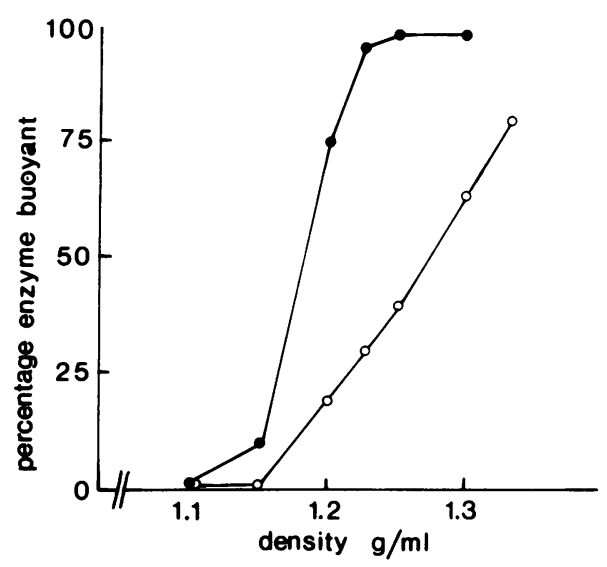

FIGURE 8 Ultracentrifugal flotation of nitroanilide hydrolase activity fractionated from rheumatoid synovial fluid. The percentage of enzyme buoyant (in the top third of the tube) is plotted against the density at which centrifugation was performed. 0 , the void volume peak from Sepharose 4B fractionation of rheumatoid synovial fluid (see Fig. 8) and $O$, the second enzyme peak from Sepharose 4B. 10-ml tubes were centrifuged at $50,000 \mathrm{rpm}$ for $20 \mathrm{~h}$ at $15^{\circ} \mathrm{C}$.

part $(95 \%)$ of the nitroanilide hydrolase activity was unlikely to be due to leukocyte elastase or indeed any proteinase bound to $\alpha_{2} \mathrm{M}$. Although inhibition studies of crude material such as synovial fluid can be subject to error, the failure of Dip-F to cause any significant inhibition after preincubations up to $10 \mathrm{~h}$, as well as its failure to inhibit the enzyme activity in either peak from Sepharose 4B chromatography, was very strong evidence against the activity being due to any serine proteinase such as leukocyte elastase. Furthermore Dip-F failed to inhibit the enzyme eluted from the top of the polyacrylamide gel after electrophoresis.

The ultracentrifugal flotation experiments showed that the two forms of the enzymic activity separated by Sepharose 4B chromatography were both associated with some lipid. The larger form contained more lipid than the smaller form since it had a lower buoyant density. It is not known whether the two forms contained the same enzyme. The large form was unlikely to be a simple aggregate of the small form because it had a different buoyant density. It is possible that the small form may have arisen from breakdown of the large form. The interaction with lipid may not have been fortuitous since it was not disrupted by high salt concentrations, which usually prevent nonspecific association between protein and lipid. Although it was possible that the enzyme may have been forming aggregates with plasma lipoproteins present in synovial fluid, the buoyant densities and chromatographic characteristics of both forms did not correspond to those of plasma lipoproteins. The large form behaved like very low density lipoproteins or chylomicrons on
Sepharose 4B chromatography but had a much higher density than either of these. The small form had a higher density than high density lipoprotein and eluted slightly earlier from the Sepharose column. The large form could well have been some type of membrane fragment, perhaps arising from cell breakdown; its buoyant density was consistent with this suggestion. The small form could have been a low molecular weight enzyme aggregated with lipid or even a high molecular weight lipoprotein enzyme.

The activities of nitroanilide hydrolase were, with one exception, higher in the synovial fluid than in the plasma so the enzymic activity probably arose within the joint cavity. Studies are in progress to see whether similar activity can be found in the synovial membrane or synovial fluid leukocytes.

Amino acid and peptide nitroanilide substrates are generally hydrolyzed by proteinases and aminopeptidases. The synovial fluid enzyme is unlikely to be an aminopeptidase since the terminal amino group of Suc-(Ala) ${ }_{3}-\mathrm{NPhNO}_{2}$ is blocked. Therefore the enzyme responsible is very likely to be a proteinase. No metal-dependent proteolytic activity was detected in the enzyme-rich fractions prepared by ultracentrifugal flotation, but this does not mean that the synovial fluid enzyme was not a proteinase. The enzyme may have been hindered from attacking a high molecular weight or powder substrate because of its association with other material or the substrate specificity of the enzyme may have been such that the substrates used were unsuitable.

Identification of the enzyme as well as determination of any role it might play in tissue destruction await its purification.

\section{ACKNOWLEDGMENTS}

I wish to thank Professor W. Watson Buchanan for allowing me to study his patients, Dr. J.-P Mathieu for supplying me with so many samples of synovial fluid, and Dr. A. J. Barrett of the Strangeways Research Laboratory, Cambridge, for his help and criticism during revision of the manuscript.

I am grateful to CIBA Research Laboratories Horsham, Sussex, England for their financial support.

\section{REFERENCES}

1. Dingle, J. T. 1962. Lysosomal enzymes and the degradation of cartilage matrix. Proc. R. Soc. Med. 55: 109-111.

2. Weissman, G. 1972. Lysosomal mechanisms of tissue injury in arthritis. N. Engl. J. Med. 286: 141-147.

3. Janoff, A., G. Feinstein, C. J. Malemud, and J. M. Elias. 1976. Degradation of cartilage proteoglycan by human leukocyte granule neutral proteases - A model of joint injury. I. Penetration of enzyme into rabbit articular cartilage and release of ${ }^{35} \mathrm{SO}_{4}$-labeled material from the tissue. J. Clin. Invest. 57: 615-624.

4. Keiser, H., R. A. Greenwald, G. Feinstein, and A. Janoff. 1976. Degradation of cartilage proteoglycan by human leukocyte granule neutral proteases - A model of joint 
injury. II. Degradation of isolated bovine nasal cartilage proteoglycan. J. Clin. Invest. 57: 625-632.

5. Janoff, A., and J. Scherer. 1968. Mediators of inflammation in leukocyte lysosomes. IX. Elastinolytic activity in granules of human polymorphonuclear leukocytes. J. Exp. Med. 128: 1137-1155.

6. Feinstein, G., and A. Janoff. 1975. A rapid method for purification of human granulocyte cationic neutral proteases; purification and further characterisation of human granulocyte elastase. Biochim. Biophys. Acta. 403: 493505.

7. Gerber, A. C., J. H. Carson, and B. Hadorn. 1974 Partial purification and characterisation of a chymotrypsin-like enzyme from human neutrophil leukocytes. Biochim. Biophys. Acta. 364: 103-112.

8. Feinstein, G., and A. Janoff. 1975. A rapid method for purification of human granulocyte cationic neutral proteases: purification and characterisation of human granulocyte chymotrypsin-like enzyme. Biochim. Biophys. Acta. 403: 477-492.

9. Lazarus, G. S., J. R. Daniels, R. S. Brown, H. A. Bladen, and H. M. Fullmer. 1968. Degradation of collagen by a human granulocyte collagenolytic system. J. Clin. Invest. 47: 2622-2629.

10. Ohlsson, K., and I. Olsson. 1973. The neutral proteinases of human granulocytes. Isolation and partial characterisation of two granulocyte collagenases. Eur. J. Biochem. 36: $473-481$.

11. Ohlsson, K. 1975. $\alpha_{1}$-antitrypsin and $\alpha_{2}$-macroglobulin interactions with human neutrophil collagenase and elastase. Ann. N.Y. Acad. Sci. 256: 409-419.

12. Mehl, J. W., W. O'Connell, and J. DeGroot. 1964. Macroglobulin from human plasma which forms an enzymatically active compound with trypsin. Science (Wash. D. C.). 145: 821-822.
13. Barrett, A. J., and P. M. Starkey. 1973. The interaction of $\alpha_{2}$-macroglobulin with proteinases. Characteristics and specificity of the reaction, and a hypothesis concerning its molecular mechanism. Biochem. J. 133: 709-724.

14. Bieth, J., B. Spiess, and C. G. Wermuth. 1974. The synthesis and analytical use of a highly sensitive and convenient substrate of elastase. Biochem. Med. 11: 350-357.

15. Pryce-Jones, R. H., J. Saklatvala, and G. C. Wood. 1974. Neutral proteinase from the polymorphonuclear leucocytes of human rheumatoid synovial fluid. Clin. Sci. Mol. Med. 47: 403-414.

16. Saklatvala, J. 1975. The proteinase inhibitors of human plasma. Ph.D. Thesis. University of Strathclyde, Glasgow, Scotland.

17. Erlanger, B. F., N. Kokowsky, and W. Cohen. 1961. The preparation and properties of two new chromogenic substrates of trypsin. Arch. Biochem. Biophys. 95: 271278.

18. Saklatvala, J., G. C. Wood, and D. D. White. 1976. Isolation and characterisation of human $\alpha_{1}$-proteinase inhibitor and a conformational study of its interaction with proteinases. Biochem. J. 157: 339-351.

19. Charney, J., and R. M. Tomarelli. 1947. A colorimetric method for the determination of the proteolytic activity of duodenal juice. J. Biol. Chem. 171: 501-505.

20. Pryce-Jones, R. H., and G. C. Wood. 1975. Purification of granulocyte neutral proteinase from human blood and rheumatoid synovial fluid. Biochim. Biophys. Acta. 397: 449-458.

21. Havel, R. J., H. A. Eder, and J. H. Bragdon. 1955. The distribution and chemical composition of ultracentrifugally separated lipoproteins in human serum. $J$. Clin. Invest. 34: 1345-1353. 